Provided for non-commercial research and education use. Not for reproduction, distribution or commercial use.

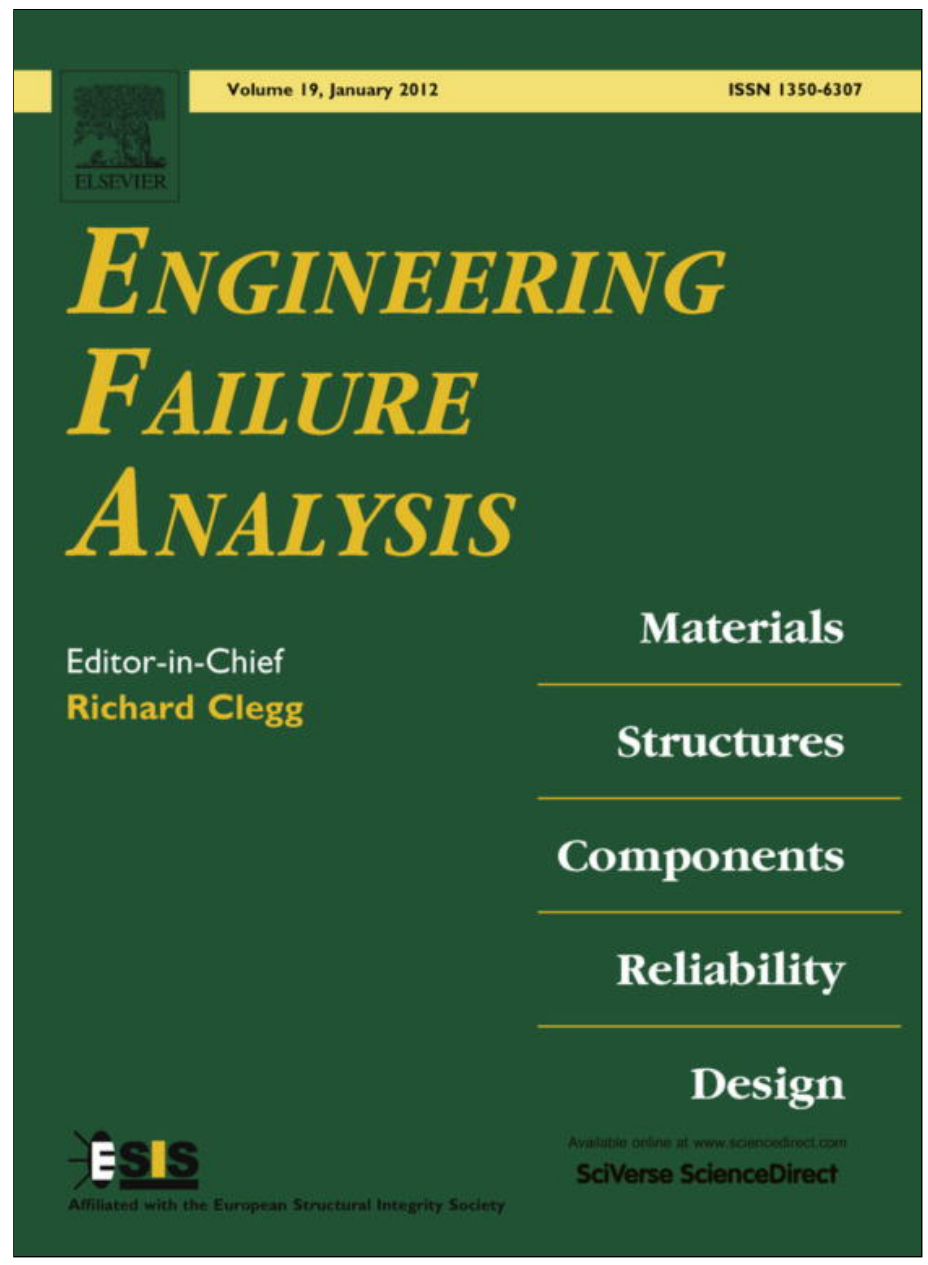

(This is a sample cover image for this issue. The actual cover is not yet available at this time.)

This article appeared in a journal published by Elsevier. The attached copy is furnished to the author for internal non-commercial research and education use, including for instruction at the authors institution and sharing with colleagues.

Other uses, including reproduction and distribution, or selling or licensing copies, or posting to personal, institutional or third party websites are prohibited.

In most cases authors are permitted to post their version of the article (e.g. in Word or Tex form) to their personal website or institutional repository. Authors requiring further information regarding Elsevier's archiving and manuscript policies are encouraged to visit:

http://www.elsevier.com/copyright 


\title{
Effect of salt crystallization ageing on the compressive behavior of sandstone blocks in historical buildings
}

\author{
Marco Ludovico-Marques ${ }^{\mathrm{a}, *}$, Carlos Chastre ${ }^{\mathrm{b}}$ \\ ${ }^{a}$ CICC, Barreiro School of Technology, Polytechnic Institute of Setúbal, Portugal \\ ${ }^{\mathrm{b}}$ UNIC, Dept. of Civil Engineering, FCT, Universidade NOVA de Lisboa, Portugal
}

\section{A R T I C L E I N F O}

\section{Article history:}

Received 22 June 2012

Received in revised form 22 August 2012

Accepted 22 August 2012

Available online 10 September 2012

\section{Keywords:}

Sandstone

Salt crystallization

Compression

Behavior

\begin{abstract}
A B S T R A C T
Sandstone building stones are important in the building elements of Portuguese monuments, particularly in the western and southern regions. Alveolization due to salt crystallization was the most important degradation pattern found in the old sandstone façades of buildings in the village of Atouguia da Baleia. Because weathering progressively increases porosity in stones, experimental research was conducted on the most porous variety of sandstone, which is similar to the type of stones found in the façades of ancient buildings in that village. An automatic salt crystallization accelerated ageing chamber was developed. Monotonic and cyclic uniaxial compressive tests were carried out on samples after sodium chloride crystallization ageing tests had been performed, in order to assess the compressive mechanical behavior of sandstone during accelerated ageing. The results of stress-strain compression diagrams showed a clear decreasing trend in the values of mechanical parameters during the salt crystallization ageing progress. The difference in compressive strength values between monotonic and cyclic compression also decreases with as salt crystallization ageing progresses. A predictive equation that correlates the compressive strength of sandstones with salt crystallization ageing cycles is proposed.
\end{abstract}

(c) 2012 Elsevier Ltd. All rights reserved. 